http://dx.doi.org/10.18778/1508-1117.23.08

Anna Janiszewska

\title{
THE SPATIAL NATURE OF MATRIMONIAL BEHAVIOURS ${ }^{1}$
}

\begin{abstract}
The work presents a research approach of behavioural geography to the analysis of man's spatial behaviours. Matrimonial behaviours constitute those which are influenced to a greater degree by behavioural factors (social status, education, nationality, religion) than spatial factors. Although in the process of marital selection, the future spouse's spatial features are important during selection, other features, such as demographic and social ones are also taken into consideration. This study presents selected theoretical approaches to marital selection. Yet another purpose thereof is to present and exemplify the spatial dimension of marital selection in Poland on different levels: of voivodeships, of city-village units and of cities (on the example of Łódź).
\end{abstract}

Key words: matrimonial behaviours, marital selection, behavioural geography.

\section{Introduction}

The new research approaches in geography regarding spatial behaviours were developed in the 1960s together with the appearance of behavioural orientation in geographical studies. The main idea of behavioural studies was to reject the concept of the always-rational man, treated as homo oeconomicus. In behavioural geography man is perceived as homo psychologicus, choosing and making decisions not always rationally, but on the basis of data possessed (Węcławowicz 2003). Behavioural orientation encompasses a wide spectrum of research issues. Cognitive maps, spatial settlement preference maps, shopping places preference maps and so on, have been constructed in the field of city geography within this orientation. To achieve that, techniques borrowed from psychology and sociology were used (Walmsley, Lewis 1997). The behavioural approach enables the empirical or humane inclination of studies. The purpose of the former is to achieve an objective verification of the results and their intersubjective conformity. The latter describes and literally reconstructs various environments in order to uncover their obvious meanings (Walmsley, Lewis 1997).

\footnotetext{
${ }^{1}$ Pieces of text have already been published in the book Dobór przestrzenny $i$ demograficzno-społeczny matzeństw zawieranych w Łodzi, 2007, Ed. UŁ, Łódź.
} 
Three philosophical currents played a crucial role in the development of behavioural studies in geography: phenomenology, existentialism and idealism (Jędrzejczyk 2001). Phenomenology focuses on the relationship between experience and meaning in the interactions between man and his environment. It assumes that in social sciences, the researcher alters the subject during the study itself and due to studying it. Phenomenologists claim that man is not dependant on the surrounding world and that learning the world is achieved through a person's own consciousness - therefore social sciences should study the man's experiencing of the world. The researcher attempts to understand the behaviour of the studied people, more specifically - intentions that motivate their behaviour - by empathizing and identifying with them (Walmsley, Lewis 1997). In idealism, mental activities are the base of human existence. It means that world can be experienced only through thoughts (Guelke 1981). There is no "real" world, experienced regardless of one's mind, because each person influences this world and it is created and shaped through that person's consciousness (Moore, Golledge 1976). Idealism differs from phenomenology as it goes beyond the subjective interest in the experienced world and attempts to attain verifiable knowledge (Guelke 1981). On the base of existentialism there is the notion of man firmly set in the specific, historical and geographical facts of existence. Building on this assumption, existentialism claims that man himself emerges from the surrounding space to be able to interact with items and phenomena in his environment. These relationships with his environment are what gives meaning to human existence (Samuels 1981).

Time geography is a very unique field of research. Created and developed by T. Hägerstrand and his disciples, it became a perfect tool in describing the behaviour of individuals and their biographies in time and space, as well as the limits existing in the surrounding environment. A. Giddens (2003) indicates the value of these works: "As a result geographers, proceeding with the established traditions of social theory, contributed to the development of social thought in a major way. I think that their works, despite bringing forth generally-meaningful ideas, still remain unknown to the majority of other social scientists"2. T. Hägerstrand (1975) studied the interactions of individuals moving in time and space; these interactions created the layout of bundles of social meetings and gatherings on some "stations" - the points in time and space within the set boundaries (in homes, on the streets, in cities, countries). The result was a general diagram of movements in time and space within a "life cycle". For example, a person living with parents until marriage and then moving can be connected to the change of workplace, therefore the modification in the daily work-home route. Typical life routes undergo some alterations due to the economic conditions, a possible divorce, career advancements and a number of other factors (Giddens 2003).

\footnotetext{
${ }^{2}$ All quotations are rendered by a translator.
} 
The work presents a research approach of behavioural geography to the analysis of man's spatial behaviours. The article discusses the issue of spatial aspects of matrimonial behaviours. Marital selection constitutes these demographic behaviours that are influenced not only by demographic and social determinants, but also by spatial features. This study presents selected theoretical approaches to marital selection. Yet another purpose thereof is to present and exemplify the spatial dimension of marital selection in Poland on different levels: of voivodeships, of city-village units and of cities (on the example of Łódź).

\section{Matrimonial behaviours and their spatial dimension}

\subsection{Theoretical approaches}

Demographic behaviour is defined as "the whole of reactions caused by outside factors (the situation) or inside factors (needs, intentions, aspirations) regarding the selection of a partner, a place of residence and the reproduction and health strategies. Therefore, these constitute real reactions, assuming they are conscious" (Szukalski 2012). These behaviours include those which have a greater connection to the geographic space, e.g. migrations (the economic development of certain regions), mortality (the status of the environment), but also procreative and matrimonial behaviours, which, to a greater or lesser degree, are influenced by behavioural factors (social status, education, nationality, religion) - P.A. Comptom (1991).

An especially interesting subject of research comprises the role of distance and space in stimulating or delaying social interaction (Irving 1975; Smith 1978). The research has shown that the closeness and the time of residing in a given place is a crucial factor that broadens the circle of friends, but does not determine the intensity of human relationships. Aside from the above-mentioned factors, local relations are influenced by belonging to a given social group or club and local friendships (Golledge, Zannares 1973). It is obvious that people whose social statuses are different in the social space and structure also differ in their knowledge about potential places of residence, their viewpoint on them and the level of exploiting the possibilities thereof (Jones 1980). In accordance with this approach, it is assumed that people migrate because they believe they will be able to fulfil their aspirations better elsewhere. Among the unrestricted migrations there are those caused by economic factors - unemployment, higher salaries and work careers and they are considered long-distance movements. Making matrimonial decisions or entering into informal relationships often results in the change of place of residence for one or both partners. In that case, short-distance population migration occurs (Shaw 1975; Lewis 1982). 
Mobility due to a move depends mainly on the level of dissatisfaction with a person's living conditions. The level changes together with the transformations of the cycle of family life (Thorns 1980). During this cycle, events which cause the decrease in the readiness to migrate can be pointed out. For instance, marriage and giving birth are events that increase the possibility of migration. However, the factor of the cycle of family life cannot be considered a sole variable. W.A. Clark (1976) and D.H. Weinberg (1979) claimed that economic factors constitute the real reasons for intra-city mobility. Many families intend to live elsewhere but lack financial means (Jones 1981).

The cognitive concept of migratory behaviours by J. Dzieciuchowicz (1995) takes into account the factors controlling these behaviours, the procedures of processing appropriate data, the judgement of migration results and their motivational mechanism. The author considers internal factors (data registered in human memory) and outside factors (data received by the individual through the social, cultural, physical environment) as those stimulating migratory behaviours. The evaluation of the subjective values of the results of potential migration, including positive ones (e.g. increased social prestige, better living conditions), negative ones (e.g. the enmity of the new environment, hardships in commuting) and neutral ones (similar neighbourhood) has a crucial influence on the decision-making process on the subject of migration. The source of migratory motivation, according to the analyzed concept, can be found within the information process.

Matrimonial behaviours connected to the selection of a partner require making a personal decision which reflects the person's expectations about the future partner. Marital selection is determined by demographic, social and spatial features of potential relationship candidates. Making a decision about entering into a relationship is personal in nature and depends largely on the information the partners possess about each other.

On the basis of the subject literature, three methods of analyzing the selection of a spouse can be distinguished (fig. 1). The first one treats this choice as a selection process. The researchers attempt to determine the factors which prompt the given types of men to search for the given types of women and vice-versa. The researchers' attention is focused on the final result of the selection, the analysis of its social determinants and the search for the factors restricting the freedom of couple-making. This method of research originated from the observation noting that a high percentage of marriages is characterized by a high number of similarities in social qualities between the spouses. The majority of studies is focused on the analysis of marriage selection process. The second of the mentioned methods analyzes the selection of a spouse as a developmental process during which a couple goes through a series of relationship stages, from the first chance meeting, through dating, until the decision to get married. This type of conducting 
research is not very popular. Finally, the third method, developed by H. Wienold (1972) constitutes the combination of both the above-mentioned types of analyses which occur separately.

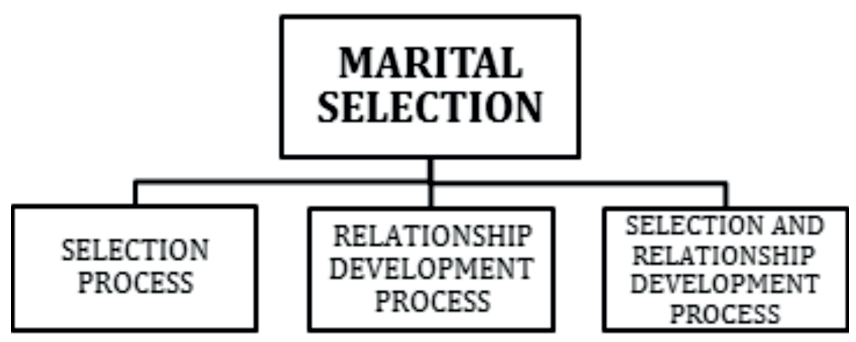

Fig. 1. Models of marital selection

Source: personal elaboration on the basis of literature

Since the 1950s, in the concepts explaining the mechanisms of marital selection, the principle of endogamy is indicated, which constitutes the selection of people with the same or similar characteristics. R.F. Winch (1958) introduced the social factors determining the choice of a potential spouse, using the notion of "the field of electives". In his opinion, there are several variables which allow to see the homogamy of spouses. These include: race, religion, social class, the size of the spouses' respective occupational groups, place of residence, age, income and education level. These variables work to select a group of people for each individual, with which he/she is most likely to interact. Therefore, these variables determine with whom a person will meet and, according to Winch, introduce for each individual a "field of eligible spouses", which is likely to contain the given individual's future spouse.

The concept of a "field of electives" was supplemented by A.C. Kerckhoff (1971). His analyses showed that the whole process of selection (therefore, the selection of both the first love and the fiancée) occurs within the "field of electives". However, during the selection process, on each of its stages, different significance is attached to all indicators of the "field of electives". Kerckhoff's research has shown, above all, the modification in the importance of the place of residence and education. The former, as a determining factor, decreased while moving from the first love to the fiancée stage, while the latter visibly increased.

The view claiming that the selection of a spouse is governed by the rule of social homogamy appears to be deeply rooted in literature and indisputable. Generally, there are two spheres in which the characteristics of potential spouses are looked for:

- in the diverse models of activity as well as in the diverse range and frequency of social relations in individual segments of social structure,

- in the occurrences of social norms which dictate making homogenous choices. 
In the first interpretation, social homogamy is treated as the function of possibilities. A spouse is selected from the group of "easily accessible" people, with whom one keeps in touch daily (Hollingshead 1950; Winch 1958; Good 1964). Therefore, the frequency of contacts contributes, on the one hand, to the better assessment of the selected person and, on the other, to the better evaluation of one's own chances. The amount of data needed to assess the representative of one's own social class is smaller than to assess people from other societal factions, with whom a person does not come into contact as often. The range of social contacts as well as the number and type of pieces of information associated with them also set the criteria for a partner's attractiveness. Those who belong to the same social class or social stratum as the selector, have a greater chance of being considered "attractive" than those from other social classes or strata. The second type of explanations about the homogamy of marriage is prescriptive in nature. It shows the models of similarities between the partners' characteristics as a result of some people preferring to choose those "socially" similar to themselves and being forced to make homogenous choices by the social sanctions.

\subsection{Empirical research - territorial selection in Poland}

The place of residence constitutes a feature influencing marital preferences, as it can either be a factor that makes interaction easier or an obstacle in making acquaintances (Strzelecki 1989; Mrzygłód 1996). According to Z. Strzelecki's research (1989) in Poland there was a clear tendency to marry partners from the same local communities (more than $60 \%$ of marriages happened between people from the same city, $40 \%$ included relationships between people from the same gmina). Therefore, Polish marriages were highly homogenous in terms of area. However, in their statements, the respondents from Łódź, asked about the importance of the place of residence of their future spouses, determined that it is an unimportant or highly unimportant feature (the responses of $45 \%$ of men and $44 \%$ of women). It can prove that this feature, next to other social factors, constitutes a hidden motive in the marital selection process (Warzywoda-Kruszyńska 1974).

While studying the territorial selection of newly-married couples in terms of the administrative character of the place of residence (city, village), it can be observed that more than $70 \%$ of marriages made between 1995 and 2013 constitute homogamous relationships, that is those where both partners come from either a city or a village (table 1). The tendency to enter into mixed marriages in the residents of villages (with city dwellers) was higher than in the inhabitants of cities. Interestingly, among mixed marriages there is a slight majority of relationships in which a woman from the city married a male villager. It is a phenomenon completely different to the one in the 1970s and 1980s - when in most marriages female villagers married male city inhabitants (Strzelecki 1976, 1989; Kuciarska-Ciesielska 1978). 
Table 1

Marriages in 1995-2013 according to the newly-weds' place of residence

\begin{tabular}{|c|c|c|c|c|c|c|}
\hline \multirow[b]{2}{*}{ Year } & \multicolumn{6}{|c|}{ Place of residence $(\%)$} \\
\hline & $\begin{array}{c}\text { City } \\
\text { woman } \\
- \text { city man }\end{array}$ & $\begin{array}{c}\text { City } \\
\text { woman } \\
\text { - village } \\
\text { man }\end{array}$ & $\begin{array}{c}\text { Village } \\
\text { woman } \\
\text { - city man }\end{array}$ & $\begin{array}{c}\text { Village } \\
\text { woman } \\
\text { - village } \\
\text { man }\end{array}$ & $\begin{array}{l}\text { Marriages } \\
\text { altogether }\end{array}$ & $\begin{array}{l}\text { The per- } \\
\text { centage } \\
\text { of homo- } \\
\text { gamous } \\
\text { marriages }\end{array}$ \\
\hline 1995 & 47.62 & 11.45 & 10.46 & 30.48 & 100.00 & 78.10 \\
\hline 1996 & 48.23 & 11.45 & 10.62 & 29.71 & 100.00 & 77.94 \\
\hline 1997 & 48.28 & 11.60 & 10.80 & 29.32 & 100.00 & 77.61 \\
\hline 1998 & 48.55 & 11.58 & 10.90 & 28.96 & 100.00 & 77.51 \\
\hline 1999 & 48.98 & 11.54 & 10.93 & 28.55 & 100.00 & 77.53 \\
\hline 2000 & 49.23 & 11.71 & 11.23 & 27.83 & 100.00 & 77.06 \\
\hline 2001 & 48.94 & 11.74 & 11.38 & 27.94 & 100.00 & 76.88 \\
\hline 2002 & 48.60 & 11.99 & 11.49 & 27.92 & 100.00 & 76.52 \\
\hline 2003 & 48.87 & 12.04 & 11.61 & 27.48 & 100.00 & 76.34 \\
\hline 2004 & 48.61 & 12.22 & 11.79 & 27.38 & 100.00 & 75.99 \\
\hline 2006 & 48.40 & 12.33 & 12.02 & 27.25 & 100.00 & 75.65 \\
\hline 2007 & 47.89 & 12.27 & 12.58 & 27.26 & 100.00 & 75.15 \\
\hline 2008 & 47.28 & 12.89 & 12.61 & 27.21 & 100.00 & 74.50 \\
\hline 2009 & 47.44 & 13.35 & 13.20 & 26.01 & 100.00 & 73.45 \\
\hline 2010 & 46.10 & 13.45 & 13.78 & 26.67 & 100.00 & 72.77 \\
\hline 2011 & 45.24 & 13.70 & 13.96 & 27.10 & 100.00 & 72.35 \\
\hline 2012 & 44.19 & 13.85 & 14.14 & 27.82 & 100.00 & 72.01 \\
\hline 2013 & 43.97 & 13.73 & 14.38 & 27.91 & 100.00 & 71.89 \\
\hline
\end{tabular}

Source: personal calculations on the basis of data from Roczniki Demograficzne from years 1996-2014.

This situation can be connected to, on the one hand, the varying population structure according to age and gender in cities and villages, and on the other - the change of tendencies in the directions of internal migrations. The large majority of the newly-married are people 30 years old or younger. Among people aged $18-30$, the percentage of women and men in cities is more balanced than in villages. Therefore, the lack of numerical balance in terms of gender forces - especially male villagers - to search for wives outside of their places of residence. Moreover, due to the social and economic transformations in the early 1990s, Polish villages 
are becoming more and more attractive in terms of settling. From the mid-1990s, the number of migrations from cities to villages has been increasing, and since 2000 the migration balance assumes a positive value which increases each year (in 2000 the migration balance in villages amounted to 4.2 thousand people while in $2013-31.9$ thousand). Therefore, it can be assumed that male villager is more and more often considered a good match for a city-dwelling woman as he is able to create more favourable living conditions than a man from the city.

The analyses conducted by D. Kałuża (2007) conclude that future newly-weds (both women and men) pay less and less attention to the administrative character of the partner's place of residence. It is confirmed by the values of T-Czuprow's convergence coefficient which decrease each year, from circa 0.48 in 1995 to circa 0.44 in 2004.

In 2006-2013 the percentage of marriages between people residing in the same voivodeship amounted to circa $83 \%$. The percentage of marriages in which both spouses resided in the same voivodeship prior to marriage decreased in that period in all units (table 2). However, a large diversity in the level of homogamy in the spouses' territorial selection in the spatial layout is noticeable. In that matter, voivodeships from the central coastal area through central Poland up to southern voivodeships are largely consistent. The highest number of marriages from the same voivodeship made in 2013 happened in the regions of: Silesia, Greater Poland and Lesser Poland. The most diverse in the territorial selection of spouses were the Warmian-Masurian, Świętokrzyskie, Lubusz and Opole voivodeships.

\subsection{Spatial selection of spouses according to the place of residence prior to marriage - the example of Lódź}

The selection once enclosed within the local community also signified limited possibility of marrying someone from outside of the village, city or town. Currently, due to the social and economic transformation, the territorial barrier is limited. However, it does not mean that its role in the marital selection has disappeared altogether. While studying the territorial selection of Polish citizens in 1976-1982, among others, Z. Strzelecki (1989) concluded that places of residence of fiancées (during dating period) which are too far apart are unfavourable to the development of feelings, getting to know each other, etc. It can stem from the fact that the territorial barrier still plays an important role in the selection of spouses. Therefore, it should be emphasized that the majority of people still has reasons to select their spouses from within the local communities.

Among the surveyed group of spouses more than 55\% of partners resided less than $5 \mathrm{~km}$ away from each other, and $26.9 \%$ - separated by $5-10 \mathrm{~km}$. Spouses living furthest from each other - more than $100 \mathrm{~km}$ - constitute the lowest 
Table 2

The percentage of marriages with both spouses residing in the same voivodeship prior to marriage in 2006-2013 (\%)

\begin{tabular}{|l|c|c|c|c|c|c|c|c|}
\hline \multirow{2}{*}{\multicolumn{1}{|c|}{ Voivodeships }} & \multicolumn{7}{|c|}{ Year } \\
\cline { 2 - 9 } & 2006 & 2007 & 2008 & 2009 & 2010 & 2011 & 2012 & 2013 \\
\hline Lower Silesian & 87.62 & 86.83 & 86.67 & 84.75 & 83.74 & 83.99 & 83.42 & 83.43 \\
\hline Kuyavian-Pomeranian & 87.12 & 86.51 & 85.96 & 84.67 & 83.61 & 83.17 & 83.00 & 82.74 \\
\hline Lublin & 84.55 & 85.12 & 84.16 & 82.41 & 81.69 & 81.78 & 81.05 & 81.07 \\
\hline Lubusz & 82.84 & 82.42 & 81.47 & 79.91 & 78.90 & 78.44 & 78.10 & 78.48 \\
\hline Lódź & 86.64 & 85.53 & 85.15 & 84.45 & 83.73 & 82.77 & 83.46 & 82.36 \\
\hline Lesser Poland & 87.32 & 86.63 & 85.94 & 85.13 & 84.64 & 84.48 & 84.74 & 84.83 \\
\hline Mazovian & 85.42 & 85.64 & 85.26 & 84.44 & 83.87 & 83.62 & 83.80 & 83.83 \\
\hline Opole & 82.90 & 82.04 & 81.03 & 79.82 & 78.98 & 79.35 & 78.62 & 79.76 \\
\hline Subcarpathian & 86.68 & 85.95 & 85.06 & 83.71 & 83.25 & 83.52 & 83.32 & 82.63 \\
\hline Podlaskie & 84.13 & 83.98 & 83.65 & 82.99 & 81.47 & 80.97 & 81.22 & 81.80 \\
\hline Pomeranian & 87.36 & 87.50 & 86.58 & 85.44 & 84.45 & 85.15 & 84.09 & 83.96 \\
\hline Silesian & 89.04 & 88.41 & 88.14 & 87.32 & 86.91 & 86.66 & 86.87 & 87.04 \\
\hline Świętokrzyskie & 82.12 & 81.08 & 79.90 & 78.54 & 78.81 & 76.88 & 78.23 & 76.52 \\
\hline Warmian-Masurian & 80.34 & 80.86 & 79.60 & 78.71 & 77.01 & 76.14 & 76.19 & 75.80 \\
\hline Greater Poland & 88.65 & 88.79 & 87.71 & 86.76 & 86.30 & 86.08 & 86.28 & 85.75 \\
\hline West Pomeranian & 85.67 & 85.92 & 85.58 & 83.63 & 82.94 & 81.91 & 82.34 & 83.19 \\
\hline
\end{tabular}

Source: personal calculations on the basis of data from Roczniki Demograficzne from years 2007-2014.

percentage of respondents (less than 6\%). Partners living closest to each other, with less than $1 \mathrm{~km}$ between them, were in relationships since youth, having most often met in their housing estates, courtyards, on the street or in school.

The above-mentioned data allows to conclude that the distance between the partners' places of residence is an important factor determining marital selection. According to R.F. Winch's "field of electives" theory, the place of residence is a variable - next to both partners' numerous social features - which can shape marital homogamy. All those characteristics lead to the selection of spouses out of the group of people that can be interacted with. The empirical research ${ }^{3}$ conducted at the beginning of the $21^{\text {st }}$ century in Łódź confirmed that the short distance between the places of residence of future spouses makes entering into a relation-

\footnotetext{
${ }^{3}$ Survey questionnaires have been conducted by the author in Łódź for two years from the second half of 2001 till the end of the first half of 2003. The information was collected from 1160 respondents (580 couples).
} 
ship and relationship development easier (Janiszewska 2007). The results of the studies prove that the choice of the spouse is dependent on spatial characteristics (place of birth, place of residence, place of the first meeting and places of consecutive meetings of spouses). The tendency to get married is stronger in people with the same place of residence than the same place of birth. Spatial selection according to the place of birth turned out to be synonymous with heterogamy.

The spatial range of the selection set by the distances between the partners' places of birth and places of residence indicated a more important role of the place of residence in the selection of potential spouses. The distances between the respondents' places of birth were larger than between places of residence. However, it needs to be pointed out that there were more that $42 \%$ of marriages with the distance between the spouses' places of birth of up to $5 \mathrm{~km}$, which may indicate either a low spatial mobility of the respondents and their parents or small-distance migration movements. Spatial proximity of the partner expressed in the distances between places of residence was proven to be a crucial factor in marital selection (fig. 2).

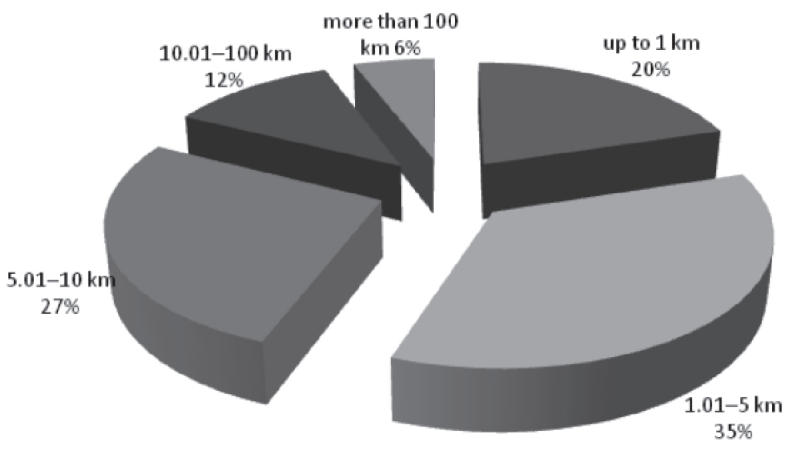

Fig. 2. Distances between the places of residence of the respondents from Łódź

Source: A. Janiszewska (2007)

The conducted typology of marriages allowed to distinguish four types in terms of marriage selection. The surveyed spouses had mostly made homogenous choices (also in terms of spatial characteristics) which was proven by the distinguished types of marriages with the highest and high level of homogamy.

\section{Conclusion}

Human spatial behaviours in many cases reflect the possibilities of processing and using information originating from the environment. The spatial dimension of human desicions is determined by the connection with space itself. Demographic 
behaviours include those in which spatial characteristics constitute a crucial element motivating to make spatial decisions (e.g. the change of the place of residence).

Matrimonial behaviours constitute those which are influenced to a greater degree by behavioural factors (social status, education, nationality, religion) than spatial factors. Although in the process of marital selection, the future spouse's spatial features are important during selection, other features, such as demographic and social ones are also taken into consideration. According to R.F. Winch, spatial features (e.g. the place of residence) together with other features constitute „the field of electives".

The emprical research of both western and Polish sociologists have provided explicit bases for the claim that marital selection is governed by the rule of endogamy, that is the selection of people with the same or similar characteristics. The Polish marital selection, in terms of spatial features, is also characterized by high regional homogeneity.

\section{BIBLIOGRAPHY}

Clark W.A., 1976, Migration in Milwaukee, „Economic Geography”, 52.

Comptom P.A., 1991, Is fertility in Western industrial countries amenable to geographical study?, [w:] Bähr J., Gans P. (eds.), The geographical approach to fertility, Im Selbstverlag des Geographischen Instituts der Universität Kiel, Kiel, s. 73-93.

Dzieciuchowicz J., 1995, Koncepcja poznawcza zachowań migracyjnych, „Acta Universitatis Lodziensis. Folia Geographica", 20.

Giddens A., 2003, Stanowienie spoleczeństwa: zarys teorii strukturacji, Zysk i S-ka, Poznań.

Golledge R.G., Zannares G., 1973, Cognitive approaches to the analysis of human spatial behaviour, [w:] Ittelson W.H. (eds.), Environment and Cognition, Seminar Press, New York.

Good W.J., 1964, The Family, New Jersey.

Guelke L., 1981, Idealism, [w:] Harvey M.E., Holly B.P. (eds.), Themes in Geographic Thoughts, Croom Helm, London.

Hägerstrand T., 1975, Time, space and human conditions, [w:] Dynamic Allcation of Urban Space, Saxon House, Farnboroug.

Hollingshead A.B., 1950, Cultural Factors in the Selection of Marriage Mates, „American Sociological Review", 15.

Irwing H., 1975, Distance, intensity, kinship: key dimensions of social interaction, „Sociology and Social Research", 60.

Janiszewska A., 2007, Dobór przestrzenny i demograficzno-spoleczny malżeństw zawieranych w Łodzi, Wydawnictwo UŁ, Łódź.

Jędrzejczyk D., 2001, Wprowadzenie do geografii humanistycznej, Wydawnictwo UW, Warszawa.

Jones R.C., 1980, The role of perception in urban in-migration: a path analytic model, „Geographical Analysis”, 12. 
Jones C., 1981, Residential mobility: an economic model, „Scottish Journal of Political Economy", 28.

Kałuża D., 2007, Otwartość doboru terytorialnego matżonków we współczesnej Polsce, „Roczniki Socjologii Rodziny”, 17, UAM.

Kerckhoff A.C., 1971, Patterns of Homogamy in Mate Selection, [w:] Anderson M. (ed.), Sociology of the Family, London.

Kuciarska-Ciesielska M., 1978, Ruchliwość przestrzenna nowożeńców, „Wiadomości Statystyczne", 1.

Lewis G.J., 1982, Human migration: a geographical perspective, Croom Helm, London.

Moore G.T., Golledge R.G., 1976, Environmental knowing: concepts and theories, [w:] Moore G.T., Golledge R.G. (eds.), Environmental knowing, Dowolen Hutchinson and Ross, Stroudsburg.

Mrzygłód H., 1996, Dobór matżeński w rodzinach marynarzy, Wydawnictwo Naukowe Uniwersytetu Szczecińskiego, Szczecin.

Samuels M.S., 1981, An existential geography, [w:] Harvey M.E., Holly B.P. (eds.), Themes in Geographic Thought, Croom Helm, London.

Shaw R.P., 1975, Migration Theory and Fact: a review and bibliography of current literature, Regional Science Research Institute, Philadelphia „Studia Demograficzne”, $57 / 58$.

Smith C.J., 1978, Self-help and social networks in the urban community, „Ekistics”, 46.

Strzelecki Z., 1976, Terytorialny i społeczny dobór nowożeńców w Polsce Ludowej, „Biuletyn IGS", 2.

Strzelecki Z., 1989, Cykl życia rodziny a migracje, „Monografie i Opracowania SGPiS”, 5.

Szukalski P., 2012, Wpływ kryzysów na zachowania demograficzne, „Wiadomości Statystyczne", 4, s. 17-30.

Thorns D.C., 1980, The role of the family life cycle in residential mobility, „Centre for Urban and Regional Studies Workshop Paper”, 69, University of Birmingham.

Walmsley D.J., Lewis G.J., 1997, Geografia człowieka. Podejście behawioralne, PWN, Warszawa.

Warzywoda-Kruszyńska W., 1974, Małżeństwa a struktura społeczna, Zakład Narodowy im. Ossolińskich, Wydawnictwo PAN, Wrocław-Warszawa-Kraków-Gdańsk.

Weinberg D.H., 1979, The determinants of intra-urban household mobility, „Regional Science and Urban Economics", 9.

Węcławowicz G., 2003, Geografia społeczna miast, PWN, Warszawa.

Wienold H., 1972, Kontakt, Einfühlung und Attraktion, Stuttgart.

Winch R.F., 1958, Mate Selection. A study of Complementary Needs, New York.

\section{PRZESTRZENNY CHARAKTER ZACHOWAŃ MATRYMONIALNYCH}

Zarys treści: Artykuł podejmuje problematykę aspektów przestrzennych zachowań matrymonialnych. Zachowania matrymonialne należą do tych, na które w większym stopniu wpływają czynniki behawioralne (status społeczny, wykształcenie, narodowość, religia) niż czynniki przestrzenne. Niemniej jednak, w procesie doboru małżeńskiego cechy przestrzenne przyszłego współmałżonka są istotne przy podejmowaniu decyzji, obok innych cech partnerów, takich jak cechy demograficzne i społeczne. W artykule przedstawiono 
wybrane podejścia teoretyczne odnoszące się do doboru małżeńskiego. Celem artykułu było także zaprezentowanie przestrzennego wymiaru doboru małżeńskiego w Polsce w różnych przekrojach: województw, jednostek miasto-wieś oraz miasta (przykład Łodzi).

Słowa kluczowe: zachowania matrymonialne, dobór małżeński, geografia behawioralna.

Dr hab. Anna Janiszewska Katedra Geografii Regionalnej i Społecznej Wydział Nauk Geograficznych, Uniwersytet Łódzki 